\title{
Different Motivations of Chinese Students Learning Japanese and English in Japan
}

\author{
Yunlong Liu', Lezhou Su${ }^{2}$ \\ ${ }^{1}$ Keio University, Tokyo, Japan \\ ${ }^{2}$ Beijing Foreign Studies University, Beijing, China \\ Email: nathan88@sfc.keio.ac.jp
}

Received 24 December 2015; accepted 19 February 2016; published 22 February 2016

Copyright (C) 2016 by authors and Scientific Research Publishing Inc.

This work is licensed under the Creative Commons Attribution International License (CC BY). http://creativecommons.org/licenses/by/4.0/

(c) (i) Open Access

\begin{abstract}
As literacy in English and Japanese is usually a part of requirements for international students applying for Japanese universities, Chinese students in Japan, like other international students whose first language is neither English nor Japanese, have to engage in learning the two foreign languages simultaneously. The focus of this research is on the learning motivations of this Chinese student population. It attempts to judge whether differences exist in terms of motivations between their English and Japanese learning; and if so, what differences are there? It also aims to investigate what variables might influence their self-regulation of Japanese and English respectively. A survey of 46 subjects was conducted using a questionnaire with questions related to ideal L2 self, international orientation, self-efficacy beliefs, instrumentality, intrinsic motivation, motivated behavior, language learning anxiety, self-regulation, learning experience, peer pressure, parent encouragement and the role of teachers. The results of Independent Sample t-Test seem to suggest that there are distinctive differences between English learning and Japanese learning in terms of motivation. Regression analysis seems to indicate that Chinese students' self-regulation in Japanese learning differs to some extent from that in English learning in the sense that they tend to be affected by different sets of variables.
\end{abstract}

\section{Keywords}

Motivational Properties, Self-Regulation, Japanese Context

\section{Introduction}

The number of Chinese students at Japanese universities has been growing and in 2014 it reached 94,000, ranking the first among all the international students there. As literacy in English and Japanese is usually a part of requirements for international students applying for Japanese universities, Chinese studentsin Japan, like other 
international students whose first language is neither English nor Japanese, have to engage in learning the two foreign languages simultaneously.

Humphreys \& Spratt (2008) claimed that a student's emotional response in learning a foreign language might vary from that in learning another one. As one's motivation is closely related to the emotion, it might be interesting to ask if a Chinese student's motivation in learning Japanese differs from that in learning English especially when the student studies both simultaneously. Learning motivation also has much to do with the learning setting, as Li (2014) claims that studying a foreign language in a second language setting is different from that in a foreign language setting. Compared with a foreign language setting, a second language setting provides learners with more opportunities to engage in authentic communication (Dörnyei, 1990). This is the case for Chinese students in Japan, whose opportunities to practice Japanese in authentic settings are much more than their opportunities to practice English. So it is interesting as well to enquire if the difference of the two foreign languages learning may lead to the difference in terms of learning motivation. A great deal of research effort has been put on the motivation of students in different countries to learn English (Iwaniec, 2014; Li, 2014; Kormos \& Kiddle, 2013). However, the research focusing on the differences in the motivation of a language learner who has to study two foreign languages simultaneously is scare.

\section{Literature Review}

According to Dörnyei (2001), motivation accounts for why second language learners begin to study foreign languages, how long they can keep studying foreign languages and how much efforts they take in studying foreign languages. Language learning motivation consists of language learning goals, the L2 Motivational Self System, some constructs concerning the nature of language learning motivation and the constructs that are related to sustaining learning activities (Iwaniec, 2014).

Language learning goals refer to integrative orientation, instrumentality, knowledge orientation and international orientation (Iwaniec, 2014). Gardner (2006) makes a distinction between instrumental and integrative goals. Gardner (2006) proposes that instrumentality refers to the practical value of using one foreign language and that integrative orientation means the willingness of learners to integrate themselves into the target language community. Clement \& Kruidenier (1983) claims that language learning goals are affected by different language learning contexts. They discover that instrumentality is more crucial for learners of English who acquire English in a foreign language learning context than those in a second language learning milieu. Furthermore, for Chinese learners of English, integrative orientation may exert no influence on the efforts they take on language learning (Chen et al., 2005). Similarly, Japanese learners of English seem to question the role of integrative orientation and regarded instrumentality as the most important language learning goal (Yashima, 2000).

According to Csizer \& Kormos (2009), knowledge orientation means the willingness of language learners to acquire more knowledge about a foreign language. On the other hand, with the advancement of globalization, English is widely used in the world. International posture, a new goal of learning one foreign language, emerges under such circumstance. According to Yashima (2002), international orientation can be defined as the interest to engage in foreign activities, such as studying overseas. International orientation has been studied in previous research projects. For instance, Lamb's (2012) project discovers that international orientation is more important for Indonesian students than knowledge orientation.

The L2 Motivational Self System is a crucial part in the language learning motivation framework (Dörnyei, 2005). Dörnyei (2005) concludes that the Idea L2 Self, Ought-to L2 Self and L2 experience comprise the L2 Motivational Self System. Ryan (2009) discovers that the idea L2 self, which means how learners image what their language proficiency would be like in the future, can enhance the motivation of second language learners. $\mathrm{Li}$ (2014) concludes that the Ideal L2 Self is closely related to integrative orientation. The ought-to L2 self refers to the qualities that learners think they should have (Iwaniec, 2014). According to Dörnyei (2009), L2 Learning Experience focuses on the immediate influence of language learning environment, such as the experience of success and the role of the teacher. According to Dörnyei (2009), L2 Learning Experience focuses on the immediate influence of language learning environment, such as the experience of success and the role of the teacher. Most previous research has verified that the role of the L2 Motivational Self System varies in different contexts (Taguchi et al., 2009; Lamb, 2012). For instance, Taguchi et al. (2009) substantiates that the effect of the L2 Motivational Self System in Asia is more salient than that in Europe.

There are also several external constructs, the roles of parents, peers and language teachers, in language learning motivation. Garden (1985) emphasizes the positive influence of parental encouragement on the motiva- 
tion of language learners. Iwaniec (2014) suggests that parents who support foreign language learning would positively affect their children's language learning. Kormos \& Kiddle (2013) concludes that students' language learning would be facilitated if their teachers can provide informative and enlightening information and feedback to them. However, based on previous studies, the role of peers is controversial (Lamb, 2012; Kyriacou \& Zhu, 2008). Lamb (2012) discovers the influence of peers would promote the learning motivation of learners, whereas Kyriacou \& Zhu (2008) indicate that the role of peers is limited among Chinese learners of English. Specific language learning contexts might either strengthen or debilitate the roles of the above-mentioned external constructs in language learning motivation. In this study, the language learning context is specified in Japan. The study participants were Chinese learners of English and Japanese living in Japan, but most of the participants' parents were not in Japan. Their language teachers and Chinese peers in Japan were influential in their lives. Under such circumstance, the roles of their parents, peers and teachers might not be the same as those found in previous studies. The present study, therefore, intends to reexamine the roles of parents, peers and teachers in language learning motivation.

There are also other crucial elements in language learning motivation, such as self-efficacy beliefs, anxiety and self-regulation (Iwaniec, 2014). Self-efficacy beliefs can be defined as how well a language learner perceives he or she can finish a task (Bandura, 1997). Magogwe \& Oliver (2007) claims that students' self-efficacy beliefs could either facilitate their foreign language acquisition or debilitate their competency of acquiring a foreign language. However, the negative role of anxiety in language learning has been verified. Anxiety is negatively correlated with learners' self-efficacy beliefs (Cheng et al., 1999). Self-regulation refers to the degree to which language learners can manage and control their learning process (Zimmerman, 2002). Zimmerman (2002) suggests that students who can self-regulate themselves could promote their language learning process (Riding \& Rayner, 1998). Iwaniec (2014) claims that motivated behaviors, intrinsic motivation and the ideal L2 self could affect Poland students' self-regulation of learning English. However, the self-regulation of Chinese learners of English has not been studies yet. Kormos \& Kiddle (2013) concluded self-regulation strategies are highly related to social and contextual factors. Facing different social and contextual factors, Chinese learners of English and Japanese in Japan might demonstrate distinctions in their self-regulation of acquiring English and Japanese respectively. Therefore, the present study aims at discovering the possible distinctions.

Previous studies have been conducted to discover the motivation properties of learners of English in a foreign language context or to compare the differences in the motivation properties of learners of English in foreign and second language contexts (Iwaniec, 2014; Li, 2014; Humphrey \& Spratt, 2008). Iwaniec (2014) concludes that knowledge orientation, international orientation and instrumental orientation are important language learning motivational properties. Furthermore, Li (2014) claims that the Chinese learners of English in a second language context would take more efforts in learning English, regard themselves as proficient users of English, and have more positive attitudes toward learning English than their counterparts in a foreign language context. What is more, Humphreys \& Spratt (2008) discovers learners of various foreign languages might differ in their motivations of learning each foreign language, and they observe that English and Putonghua are regarded as having a greater instrumental value than other foreign languages. Humphreys \& Spratt (2008) also suggests that English and the chosen languages are more popular among Hong Kong students than Putonghua.

For the purpose of discovering how L2 motivation differs between learners in different language learning contexts, comparative studies should be conducted with foreign language learners from the same cultural background (Li, 2014). Although Humphreys \& Spratt (2008) students in Hong Kong might have distinct motivations of learning different foreign languages, those students were studying just only one foreign language when the study was conducted. Against the background of globalization, however, students are required to learn two foreign languages simultaneously to be more competitive. For the Chinese students in Japan, they study Japanese in a second language context, while they acquire English in a foreign language context. Whether there are differences in their language motivation properties between learning English and Japanese remains unanswered. Therefore, the present study asks the following two research questions.

Research questions:

1) Do Chinese students in Japan who have to study both Japanese and English simultaneously differ in their motivations of learning the two languages?

2) Which factors are related to self-regulation of Chinese learners of Japanese and English respectively in Japan? 


\section{Method}

\subsection{Participants}

46 Chinese students who studied in Japan for at least one year participated in the research, when they were preparing for the Examination for Japanese University Admission for International Students (EJU) and TOEFL as well. Table 1 includes their gender, age, native place and language learning background.

\subsection{Instruments}

A questionnaire was developed on the basis of Iwaniec's (2014) version. It consists of seventy one questions in total, covering crucial elements in Japanese and English learning motivations, such as Idea L2 self, international orientation, self-efficacy beliefs, instrumentality, intrinsic motivation, motivated behavior, anxiety, self regulation, learning experience, peer pressure, parental encouragement, the role of teachers. All the subjects were required to mark each statement in a five-point Likert scale. For instance, a participant marked 5 if he or she agreed with the statement very much, and the participant marked 1 if he or she totally disagreed with a statement. All questions were in Chinese to ensure the accurate comprehension of the participants.

\subsection{Procedures}

Participants were first informed of the research purpose and then given the instructions on how to complete the questionnaire within 30 minutes allowed. Each item of question required them to rate both their Japanese and English learning motivations. Their ratings were then processed by Independent Sample t-Test and Regression Analysis in SPSS 20.0.

\section{Results}

\subsection{Research Question One}

The result indicates notable distinctions in the motivations behind English and Japanese learning. As Table 2 shows, five out of the twelve elements in language learning motivation, such as Idea L2 self, self-efficacy, intrinsic motivation, language anxiety, self-regulation, and peer pressure, differed statistically $(p<.05)$.

In Japanese learning, the subjects had better idea L2 self with higher self-efficacy and intrinsic motivation.

Table 1. Characteristics of participants.

\begin{tabular}{|c|c|c|}
\hline & \multicolumn{2}{|c|}{ Chinese participants $n=46$} \\
\hline Average age & \multicolumn{2}{|c|}{20.5} \\
\hline \multicolumn{3}{|l|}{ Gender } \\
\hline Male & \multicolumn{2}{|c|}{23} \\
\hline Female & \multicolumn{2}{|c|}{23} \\
\hline \multicolumn{3}{|l|}{ Native place } \\
\hline Eastern China & \multicolumn{2}{|c|}{35} \\
\hline Central China & \multicolumn{2}{|c|}{8} \\
\hline Western China & \multicolumn{2}{|c|}{3} \\
\hline Language proficiency level & English & Japanese \\
\hline Advanced & 2 & 22 \\
\hline Intermediate & 21 & 18 \\
\hline Poor & 23 & 6 \\
\hline
\end{tabular}


Furthermore, they were more likely to be affected by peer pressure (see Table 2). These findings suggest that their motivation behind Japanese learning should be higher than that behind English learning. The result also indicates higher level of anxiety with English learning among the subjects $(p<.05)$. Other elements in language learning motivation, such as international orientation, instrumentality, motivated behavior, self-regulation, parental encouragement, learning experience and the role of teachers, demonstrate no difference $(p>.05)$.

\subsection{Research Question Two}

Regarding to the factors affecting the self-regulation of studying Japanese and English respectively, the results of regression analysis revealed that the idea L2 self, intrinsic motivation, motivated behavior and language anxiety could be the best predictors of self-regulation of Chinese who learn Japanese in Japan (see Table 3); In contrast, motivated behavior and the role of teachers were related to self-regulation of Chinese learners of English in a Japanese context (see Table 4).

Table 2. Differences in the motivations of studying Japanese and English.

\begin{tabular}{|c|c|c|c|c|c|}
\hline & Mean of learning English & Mean of learning Japanese & $\mathrm{t}$ & df & Sig. (2-tailed) \\
\hline Idea L2 self & 3.64 & 4.40 & 3.967 & 90 & $.000^{* *}$ \\
\hline Self-efficacy & 3.45 & 4.43 & 4.580 & 90 & $.000^{* *}$ \\
\hline Intrinsic motivation & 3.80 & 4.18 & 2.393 & 90 & $.019 * *$ \\
\hline Motivated behavior & 3.28 & 3.65 & 1.842 & 90 & .069 \\
\hline Language anxiety & 2.80 & 2.31 & -2.194 & 90 & $.031^{* *}$ \\
\hline Self-regulation & 3.30 & 3.66 & 1.893 & 90 & .062 \\
\hline Peer pressure & 4.06 & 3.37 & -3.905 & 90 & $.000 * *$ \\
\hline Parent encouragement & 4.53 & 4.49 & -1.462 & 90 & .147 \\
\hline International orientation & 3.41 & 3.26 & -.769 & 90 & .444 \\
\hline Instrumentality & 3.69 & 3.64 & -.236 & 90 & .814 \\
\hline Learning experience & 2.93 & 3.15 & .914 & 90 & .363 \\
\hline The role of teachers & 4.53 & 4.49 & -.284 & 90 & .777 \\
\hline
\end{tabular}

$* * p<.005$.

Table 3. Variables influencing the self-regulation of studying Japanese.

\begin{tabular}{cccc}
\hline Viable & $B$ & SE $B$ & beta \\
\hline Idea L2 self & -.49 & .16 & $-.37^{* *}$ \\
Intrinsic motivation & .78 & .14 & $.67^{* *}$ \\
Motivated behavior & .53 & .08 & $.60^{* *}$ \\
Language anxiety & .36 & $.44^{* *}$ & .82 \\
R square & & & \\
\hline
\end{tabular}

${ }^{* *} p<.005$

Table 4. Variables influencing the self-regulation of studying English.

\begin{tabular}{cccc}
\hline Viable & B & SE B & .13 \\
Motivated behavior & .52 & $.52^{* *}$ \\
The role of teachers & -.42 & .15 \\
R Square & .83 & \\
\hline
\end{tabular}

$* * p<.005$. 


\section{Discussion}

\subsection{Why There Were Different Motivations}

\subsubsection{Different Language Goals}

The results suggest the Chinese subjects have a higher level motivation in learning Japanese than that in learning English. My research results also seem to support Humphreys \& Spratt's (2008) view that language learners may have different patterns of motivation in learning different foreign languages. As indicated by the results, the participants had better idea L2 self for Japanese learning while they were more likely to see English as an instrument. The difference in motivation might be due to the different roles Japanese and English play in their education. In most cases, their Japanese proficiency may affect the chance of being admitted by one of Japan's top-ranking universities. More importantly, the proficiency also determines their learning efficiency and effectiveness at Japanese universities because Japanese is more often than not used as class instruction language. In contrast, they learn English only to achieve a certain reasonable level in TOEFL test required by many Japanese universities. In this sense, English is not as demanding as Japanese.

\subsubsection{Different Language Learning Experiences}

Participants' past language learning experiences also contributed to their difference in motivation of studying English and Japanese. The frustrations they had suffered from English learning caused anxiety and reluctance on their part accompanied by being lack of confidence in English learning. This is not the case in their Japanese learning. As beginners of Japanese, they have not experienced any frustrations yet. Moreover, they take positive attitudes towards the language and the culture. These positive emotional and attitudinal factors led to higher level of intrinsic motivation behind their learning. Compared to English learning, their Japanese learning is characterized with longer concentration time span and more adept self-regulation. As a result, more achievements in Japanese learning were made, which in turn led to higher self-efficacy.

\subsubsection{A New Language Learning Environment}

The Chinese participants in my study studied English and Japanese simultaneously in a Japanese context. They more often than not studied Japanese together with their Chinese peers, which verifies the role of peer effect. However, they do not learn English in peer's company.

\subsection{Why There Were Different Factors Affecting Self-Regulation}

As mentioned previously, self-regulation serves a crucial role in initiating the learning process and achieving the goals. It is of necessity to pin down what elements in language learning motivation are correlated with self-regulation. My regression analysis suggested that idea L2 self, intrinsic motivation, motivated behavior and language anxiety could affect the students' self-regulation of studying Japanese, while motivated behavior and the role of teachers are related to their self-regulation of learning English. This finding partly contrasts with Iwaniec's (2014) study. Iwaniec (2014) concluded that motivated behavior, intrinsic motivation and the idea L2 self could affect Poland students' self-regulation of learning English. Clement \& Kruidenier (1983) suggested that the linguistic milieu might affect learners' language learning motivation. Self-regulation is a crucial component in language learning motivation. Therefore, the differences in the results of these two studies could be explained by the fact that the self-regulation of language learners would be affected by the language environment in which they are.

In my study, the Chinese participants' self-regulation of English study could be predicted by the role of teachers. Chinese students in Japan would encounter various difficulties in learning English. Lacking of English learning tutorials, past unpleasant English study experiences and failing to manage their time to study two foreign languages simultaneously could be possible factors contributing to their relatively low English learning motivation. The majority of the participants in my study complained that they needed more English learning tutorials when preparing all kinds of English proficiency tests in Japan. They claimed that the English teachers who can speak Chinese would facilitate their English learning and that they would be more self-regulated if English teachers could guide them to acquire English.

The finding in my study also suggested intrinsic motivation is correlated with the Chinese participants' self-regulation of learning English, which is in line with the finding of Iwaniec's (2014) study. However, Iwaniec (2014) suggested the participants in his study could derive pleasure in the process of learning English, 
which explained the correlation between self-regulation and intrinsic motivation. This analysis could not be used to explain the finding of the present study. Most participants in my sample grumbled that their past English learning experiences were unpleasant. Positive attitudes, capability and self-determination are closely related to intrinsic motivation (Deci \& Ryan, 1985). Although the Chinese participants in my study had negative attitudes toward English study, they understood the role of English in their future lives. Therefore, they had to use their self-determination to self-regulate themselves in the process of learning English.

The present study discovered that idea L2 self, intrinsic motivation, motivated behavior and language anxiety could affect the students' self-regulation of studying Japanese. Learners' experience is crucial when deciding whether to begin the learning activity. The finding of the study demonstrated that the Chinese students in Japan have higher motivation when learning Japanese, which indicated that most of the Chinese participants in this study had positive attitudes toward Japanese learning. Their positive attitudes might contribute to their relatively high intrinsic motivation. So, they could adopt effective motivated behaviors to self-regulate their Japanese study. According to the results, the mean score of the anxiety of learning Japanese was lower than that of learning English. Feeling less anxious, the participants could investigate more energy to study Japanese and self-regulate themselves effectively. Furthermore, their positive attitudes toward Japanese study and the determination to learn Japanese could explain why they imaged how proficient they would be in learning Japanese. Stimulated by the idea-L2-self images, they could better self-regulate their Japanese study.

Further studies should invite more participants and focus on the changes in the Chinese students' motivations of learning English and Japanese after they are enrolled into universities in Japan.

\subsection{Pedagogical Implications}

With the implementation of the G30 plan in Japan, more oversea students who are proficient in English but poor in Japanese are admitted to Japanese universities. Meanwhile, for being admitted to first-ranking Japanese universities, oversea students who are proficient in Japanese but poor in English have to take TOEFL or TOEIC in Japan. Both of these two groups of students would encounter tremendous pressures because they have to finish their studies, adapt to the new environment and study at least two foreign languages simultaneously. It is necessary for foreign language teachers to employ different motivating methods to facilitate students' learning of different foreign languages and take students' past learning experiences into account. Foreign language schools and universities in Japan could devise unique curriculums for foreign students to achieve their different goals. For instance, for the students who have to take TOEFL or TOEIC, specific test preparation courses should be offered, while for those students who do not need to take standardized English tests, the course aiming at improving their oral English competency should be offered Further studies should focus on the changes in the Chinese students' motivations of learning English and Japanese after they are enrolled into universities in Japan, which is of great practical importance. It is worth noticing that Chinese students in Japan would change their attitudes toward English learning as their might have more challenging personal dreams, such as furthering their study in America in the near future. Under this circumstance, their motivations of learning English and Japanese might be changed dramatically.

\section{Conclusion}

The study investigated whether Chinese students in Japan who have to study both Japanese and English simultaneously differ in their motivations of learning the two languages respectively. Furthermore, it discovered different elements affecting their self-regulation of studying Japanese and English. The findings suggested Chinese students in Japan are more interested in studying Japanese compared to studying English. Furthermore, according to Independent Sample t-Test, their language learning motivations differed statistically in the factors like idea L2 self, self-efficacy beliefs, intrinsic motivation, language anxiety, and peer pressure when studying English and Japanese respectively. Regression analysis discovered that idea L2 self, intrinsic motivation, motivated behavior and language anxiety could predict Chinese students' self-regulation of studying Japanese. By contrast, motivated behavior and the role of teachers are related to their self-regulation of learning English.

\section{References}

Bandura, A. (1997). Self-Efficacy: The Exercise of Control. New York: W. H. Freeman 
Chen, J. F., Warden, C. A., \& Chang, H-T. (2005). Motivators That Do Not Motivate: The Case of Chinese EFL Learners and the Influence of Culture on Motivation. TESOL Quarterly, 39, 609-633. http://dx.doi.org/10.2307/3588524

Cheng, Y. S., Horwitz, E. K., \&Schallert, D. L. (1999). Language Anxiety: Differentiating Writing and Speaking Components. Language Learning, 49, 417-446. http://dx.doi.org/10.1111/0023-8333.00095

Deci, E. L., \& Ryan, R. M. (1985). Intrinsic Motivation and Self-Determination in Human Behavior. New York and London: Plenum Press. http://dx.doi.org/10.1007/978-1-4899-2271-7

Dörnyei, Z. (1990). Conceptualizing Motivation in Foreign Language Learning. Language Learning, 40, 45-78. http://dx.doi.org/10.1111/j.1467-1770.1990.tb00954.x

Dörnyei, Z. (2001). Teaching and Researching Motivation. Edinburgh Gate, England: Pearson Education.

Dörnyei, Z. (2005). Psychology of the Language Learner: Individual Differences in Second Language Acquisition. Mahwah, NJ: Lawrence Erlbaum Associates.

Gardner, R. C. (2006). The Socio-Educational Model of Second Language Acquisition: A Research Paradigm. EUROSLA Yearb, 6, 237-260. http://dx.doi.org/10.1075/eurosla.6.14gar

Humphreys, G., \& Spratt, M. (2008). Many Languages, Many Motivations: A Study of Hongkong Students' Motivation to Learn Different Target Languages. System, 36, 313-335. http://dx.doi.org/10.1016/j.system.2007.09.010

Iwaniec, J. (2014). Motivation of Pupils from Southern Poland to Learn English. System, 45, 67-78. http://dx.doi.org/10.1016/j.system.2014.05.003

Kyriacou, C., \& Zhu, D. (2008). Shanghai Pupils Motivation towards Learning English and the Perceived Influence of Important Others. Educational Studies, 34, 97-104. http://dx.doi.org/10.1080/03055690701811099

Kormos, J., \& Kiddle, T. (2013). The of Socio-Economic Factors in Motivation to Learn English as a Foreign Language: The Case of Chile. System, 41, 399-412. http://dx.doi.org/10.1016/j.system.2013.03.006

Lamb, M. (2012). A Self System Perspective on Young Adolescents Motivation to Learn English in Urban and Rural Settings. Language Learning, 39, 251-275. http://dx.doi.org/10.1111/j.1467-9922.2012.00719.x

Li, Q. (2014). Differences in the Motivation of Chinese Learners of English in a Foreign and Second Language Context. System, 42, 451-461. http://dx.doi.org/10.1016/j.system.2014.01.011

Magogwe, J. M., \& Oliver, R. (2007). The Relationship between Language Learning Strategies, Proficiency, Age and SelfEfficacy Beliefs: A Study of Language Learners in Botswana. System, 35, 338-352. http://dx.doi.org/10.1016/j.system.2007.01.003

Riding, R. J., \&Rayner, S. (1998). Cognitive Styles and Learning Strategies: Understanding Style Differences in Learning and Behavior. London: D. Fulton Publishers.

Ryan, S. (2009). Self and Identity in L2 Motivation in Japan: The Ideal L2 Self and Japanese Learners of English. In Z. Dornyei, \& E. Ushioda (Eds.), Motivation, Language Identity and the L2 Self (pp. 120-143). Bristol: Multilingual Matters.

Taguchi, T., Magid, M., \&Papi, M. (2009). The L2 Motivational Self System among Japanese, Chinese and Iranian Learners of English: A Comparative Study. In Z. Dornyei, \& E. Ushioda (Eds.), Motivation, Language Identity and the L2 Self (pp. 66-97). Bristol: Multilingual Matters.

Yashima, T. (2000). Orientations and Motivations in Foreign Language Learning: A Study of Japanese College Students. JACET Bulletin, 31, 121-133.

Yashima, T. (2002). Willingness to Communicate in a Second Language: The Japanese EFL Context. The Modern Language Journal, 86, 54-66. http://dx.doi.org/10.1111/1540-4781.00136

Zimmerman, B. J. (2002). Becoming a Self-Regulated Learner: An Overview. Theory into Practice, 41, 64-70. http://dx.doi.org/10.1207/s15430421tip4102_2 


\section{Appendix A}

\section{Questionnaire}

Idea L2 Self

1. 我想象过将来我会用日语/英语进行工作。

I often imagine I can use Japanese/English in my future job.

2. 我想象过将来我会用日语/英语进行生活。

I often imagine I can use Japanese/English in my future life.

3. 我想象过将来我会流利说日语/英语。

I often imagine I can speak Japanese/English fluently in the future.

4. 我想象过将来我能用日语/英语写电子邮件。

I often imagine I can write emails in Japanese/English.

5. 我想象过将来我能看懂日语/英语文章。

I often imagine I can read Japanese/English passages.

6. 我想象过将来我能听懂日语/英语电影或电视节目。

I often imagine I can understand Japanese/English TV programs.

International Orientation

1. 我学日语/英语是为了认识更多日语国家/英语国家人士。

I try to learn Japanese/English to know more foreigners.

2. 我学习日语/英语是为了更好了解这些国家发生的事件。

I try to learn Japanese/English for understanding foreign cultures.

3. 学日语/英语能让我更好的在日后工作里与这些国家人士交流。

I try to learn Japanese/English to communicate with Japanese/English native speakers.

4. 学日语/英语能让我感觉到我是日语国家/英语国家的一员。

I try to learn Japanese/English for integrating myself into their communities.

5. 我学习日语/英语是因为日语/英语是世界上重要的语言。

The importance of Japanese/English stimulates me to learn Japanese/English.

Self-Efficacy Beliefs

1. 我很确定我以后在工作中能成功使用日语/英语。

I am pretty sure I can use Japanese/English proficiently in my future job.

2. 我很确定我以后能成功用日语/英语表达自己的思想。

I am pretty sure I can use Japanese/English to express my opinions.

3. 我很确定我以后能听懂日语/英语电影与电视节目。

I am pretty sure I can understand Japanese/English TV programs and films.

4. 我很确定我以后能用日语/英语写出自己的思想与观点。

I am pretty sure I can write my opinions in Japanese/English.

5. 我很确定我以后能用看懂日语/英语的书籍与报纸。

I am pretty sure I can read Japanese/English newspapers.

\section{Instrumentality}

1. 我学习日语/英语是为了为在国内就业增加竞争力。

I learn Japanese/English to improve my competitiveness in China.

2. 我学习日语/英语是为了能在跨国企业工作。

I learn Japanese/English for being employed by a transnational enterprise.

3. 我学习日语/英语是为了能在国外旅游。

I learn Japanese/English for travelling abroad.

4. 我学习日语/英语是为了职场的升职。

I learn Japanese/English to get a promotion.

5. 我学习日语/英语是为了能通过各类大学升学考试。

I learn Japanese/English for performing well in all standardized language proficiency tests.

6. 我学习日语/英语是为了能在日本/英语国家生活。 
I learn Japanese/English for living in Japan or English speaking countries.

Intrinsic Motivation

1. 我学习日语/英语是因为自己的兴趣。

I learn Japanese/English out of my own interest.

2. 我很想熟练的掌握日语/英语。

I want to acquire Japanese/English fluently.

3. 能用日语/英语解决一些问题会让我有满足感。

I feel satisfied if I can use Japanese/English to solve problems.

4. 我很享受学习日语/英语的过程。

I do enjoy the process of learning Japanese/English.

5. 我很主动的想知道不认识的日语/英语单词的意思。

I want to understand the meaning of those unknown Japanese/English words.

6. 我看到自己在日语/英语上的进步会很满足。

I am satisfied with my improvements in learning Japanese/English.

Motivated Behavior

1. 我会用尽全部努力去学习日语/英语。

I always endeavor to learn Japanese/English.

2. 我学日语/英语时候经常会超额完成老师布置的作业。

I always finish my Japanese/English assignments in time.

3. 我尽最大努力每天都在坚持日语/英语学习。

I try my best to learn Japanese/English every day.

4. 我不会逃避日语/英语作业。

I enjoy finishing my Japanese/English assignments.

5. 我在日语/英语课堂上总是认真听讲。

I can fully concentrate on my Japanese/English classes.

6. 我总是在日语/英语上参与老师提问与互动。

I always answer the questions raised by my Japanese/English teachers.

Language Learning Anxiety

1. 我很害怕在日语/英语课堂上被老师要求回答问题。

I do feel nervous if I am required to answer questions in Japanese/English.

2. 即使我有认真准备我还是很怕上日语/英语课。

I do feel nervous in my Japanese/English classes even if I have prepared well.

3. 我很担心日语/英语考试会不及格。

I always feel nervous about the results of my Japanese/English tests.

4. 我在上日语/英语课的时候会比上别的科目更紧张。

Compared to other subjects, I feel more nervous in my Japanese/English classes.

5. 我很担心别人嘲笑我的日语/英语水平。

I am afraid of being mocked by other classmates about my Japanese/English proficiency.

6. 用日语/英语交流时候我总是觉得很紧张。

I feel nervous when I speak Japanese/English.

Self-Regulation

1. 如果我有日语/英语学习问题, 我总是愿意用各种方法解决它们。

I can always solve the problems in the process of studying Japanese/English.

2. 如果在日语/英语课堂上碰到了问题, 我总是愿意找老师和同学帮忙。

I can always turn to my classmates or teachers for help if I have some problems in learning Japanese/English.

3. 我总是用尽所有机会锻炼日语/英语。

I can always seize every chance to practice my Japanese/English.

4. 我会努力背日语/英语单词。

I always try my best to memorize Japanese/English vocabularies. 
5. 我有自己的独特有效的方法让日语/英语学习变的有趣。

I can always enhance my Japanese/English study efficiency.

6. 在学习日语/英语时, 我会给自己创造一个良好舒适的环境。

I can provide myself with a better Japanese/English study environment.

7. 我会努力学习日语/英语直到达到我的目标。

I will endeavor to study Japanese/English well to achieve my goals.

Learning Experience

1. 从前的日语/英语学习经历帮助了我学好这门语言。

My past experiences facilitate my Japanese/English study.

2. 我很喜欢从前日语/英语课堂上的气氛。

I did enjoy the atmosphere in my past Japanese/English classes.

3. 从前我总是特别期待日语/英语课。

I enjoyed learning Japanese/English when I was young.

4. 从前在学校上课时, 觉得日语/英语课的时间过的很快。

I felt happy when I was in my Japanese/English classes.

5. 从前我总希望有更多的日语/英语课。

I hoped there would be more Japanese/English classes.

6. 从前我就对日语/英语文化充满兴趣。

I was interested in the Japanese/English cultures when I was a child.

Peer Pressure

1. 我的朋友们都认为学习日语/英语很重要。

My friends think that it is important to learn Japanese/English.

2. 我的朋友们都认为学好日语/英语是高素质的表现。

My friends think that being proficient in Japanese/English is a symbol of well-educated.

3. 我的朋友们都认为学好日语/英语是一件很光荣的事情。

My friends think being proficient in Japanese/English is glorious.

4. 我的朋友们总会鼓励我学好日语/英语。

My friends always encourage me to learn Japanese/English diligently.

5. 我的朋友们认真学习日语/英语时, 我也会被影响着去学。

I am always affected positively when my friends learn Japanese/English diligently.

6. 我亲密的好友们日语/英语很优秀, 所以我想和他们一样。

My best friends acquire Japanese/English proficiently, so I want to be as excellent as them.

\section{Parental Encouragement}

1. 我父母觉得学习日语/英语很重要。

My parents think that it is important to learn Japanese/English.

2. 我父母认为学习日语/英语是高素质的表现。

My parents think being proficient in Japanese/English is a symbol of well-educated.

3. 我父母总是愿意出钱让我上日语/英语辅导班。

My parents are willing to pay extra fees to improve my Japanese/English proficiency.

4. 我父母总是督促检查我的日语/英语学习。

My parents always care about my Japanese/English study.

5. 我的父母总是为我创造更多锻炼日语/英语的条件。

My parents always try their best to better my Japanese/English study environment.

6. 我的父母日语/英语很好。所以我想和他们一样。

My parents acquire Japanese/English proficiently, so I want be as excellent as them.

The Role of Teachers

1. 我认为老师在我学习日语/英语的过程中意义非常重大。

My teachers think that it is important to learn Japanese/English.

2. 我的老师总是鼓励我们学好日语/英语。 
My teachers always encourage me to learn Japanese/English diligently.

3. 当老师课堂活跃时我会更愿意学日语/英语。

I am always stimulated by my Japanese/English teachers who adopt a vivid teaching style.

4. 当我佩服某位老师时, 我会愿意学习他讲授的日语/英语课。

I learn Japanese/English actively if I admire my Japanese/English teachers.

5. 老师有效而励志的学习方法会鼓励我用心学好日语/英语。

If I am touched by the inspiring experiences of my Japanese/English teachers, I will study Japanese/English diligently.

6. 当老师认真负责时, 我会配合他学好日语/英语。

If my Japanese/English teachers are responsible, I will study Japanese/English diligently. 